\section{Economic Aspects of the Cotton Trade}

"World Cotton Production and Trade" is the first of a series of studies of the principal agricultural products on the world market to be published by the International Institute of Agriculture, Rome (price 30 lire). This comprehensive monograph, consisting of 480 pages and 20 maps and diagrams, is divided into four main sections. The first deals with the geography of cotton production, describing the agricultural conditions of the humid and subhumid zones of the rain-grown crop, and the arid or semi-arid zone of irrigated cotton. Part 2 describes the conditions of cotton marketing and movements of cotton prices, while Part 3 is concerned with the evolution of world cotton trade. The fourth part deals with the national and international aspects of the industry, separate sections being devoted to the principal countries concerned. It is evident that the economic problems of the cotton trade are closely linked up with the wider financial and commercial problems of the world. The relatively large expansion of the smaller cotton countries during an economic crisis simultaneously with the general contraction of the world cotton industry, presents one of the most significant aspects of the world economic problem. The position was aggravated by the policy of the United States of maintaining cotton prices at an artificially high level and closing their market to European goods. It is considered that from the point of view of a rational world economic system, the various branches of agriculture should be developed in those parts of the world which are most suitable. Under such a system the United States would regain its position on the world cotton market, which is regarded as its full right, but the conditions of such a recovery would be the abandonment in all countries of the prevailing tendency towards economic isolation and a development of a greater degree of international co-operation.

\section{Progress in the Meteorological Office}

THF eighty-second year of the Meteorological Office is referred to in the annual report of the Director for the year ended March 31, 1937, as one of planning and preparation with the object of providing the greatly extended meteorological services required by the expanding Royal Air Force and by the increase of flying on civil air routes. These projected increases of meteorological activity have made it necessary for new staff to be recruited and trained in the special work required of them; in particular, the need for trained forecasters has had to be met in order to staff the principal forecasting centres on the various flying routes. The new Empire Air Mail Scheme led to the formation of a new division of the Meteorological Office in 1935 to organize the meteorological services of the trans-Atlantic and Empire air routes, the duty of advising the Govermments of territories traversed by the routes having devolved on the Meteorological Office, and throughout the year under review that division was preparing for the new mail service. The forecast and aviation division has given particular attention to the information required by civil and
R.A.F. aircraft in connexion with flying in and through clouds-information about the winds to be expected and warnings of dangerous conditions likely to lead to ice accretion between certain heights in strata where temperature lies between $0^{\circ} \mathrm{F}$. and $35^{\circ}$ F. and other circumstances are favourable for such accretion. It has now been determined that really dangerous conditions are scarcely ever found when temperature is more than a few degrees above or below the freezing point.

\section{Motor Traffic and Wild Life}

IN a discursive and interesting paper read before the Zoological Society of London (Proc. Zoo. Soc., Ser. A, 173 ; 1937), Surgeon Rear-Admiral Beadnell has given an indication of the destruction of wild creatures caused by motor traffic in Great Britain. In the years 1932-36, in travelling by motor-car and pedal-cycle on roads in England, Wales and Scotland, he counted 2327 dead animals in 10,000 miles, or 23 in every hundred miles. The kill was made up in the following proportions: birds 81 per cent (1885 individuals), rabbits 14 per cent, hedgehogs 4 per cent, rats 0.5 per cent, and the remainder was made up of frogs, toads, moles, snakes, dogs, cats, two sheep and one forest pony. It may be taken that the number counted during a rapid survey falls far short of the total number slain, and indeed were it not that many motorists when driving are highly regardful of wild creatures, the number would be much greater than it is. But the count does not suggest that motor traffic will make appreciable inroads upon the stock of wild animals, for the numbers are insignificant compared with the rate of increase of the common species which usually fall victims. An odd death which came to the notice of the writer was that of a dog fox in beautiful pelage, which during a snowstorm in the north-east of Scotland leapt over a stone wall against the wings of a heavy lorry.

\section{Policy in Pig-Feeding}

THE pig and bacon industry in Great Britain is dependent upon imported and home-grown cereals, and during the last twelve months feeding costs have risen by 30 per cent without a compensating rise in the price of bacon. The Bacon Development Board has accordingly completed an inquiry into the possibility of replacing cereals by other foodstuffs, and the report of A. N. Duckham has been published as Bulletin No. 2, "Substitutes for Cereals in PigKeeping" (Bacon Development Board, 1937. Price $2 s$.). The general conclusion is that if some sacrifice of growth rates and carcass quality is allowed and adequate facilities for growing and storing substitutes are made available, then cereals may be replaced in part by potatoes, sugar-beet and other home-grown root and fodder crops or by-products either in fresh or processed forms. At present, the use of these cereal substitutes may not be economical in Great Britain, but conditions may arise when cereals, home produced or imported, may be in short supply or at greater cost, and under such conditions it is 